\title{
Eesti kõrgharidus institutsionaalse akrediteerimise tulemuste taustal ehk Mida juhid peaksid teadma
}

\author{
Maiki Udama ${ }^{\text {al }}$, Riin Seema ${ }^{\text {a }}$, Heli Mattisen ${ }^{a}$ \\ a Sihtasutus Archimedes, Eesti Kõrghariduse Kvaliteediagentuur
}

\begin{abstract}
Annotatsioon
Artikli aluseks on 2014. aastal Eesti Kõrghariduse Kvaliteediagentuuris tehtud institutsionaalse akrediteerimise hindamisaruannete kvalitatiivne analüüs, millega selgitati välja Eesti kõrgkoolide peamised tugevad ja nõrgad küljed. Artikli eesmärk on teavitada haridusüldsust rahvusvaheliste ekspertide hinnangutest ja soovitustest Eesti kõrgkoolidele ning pakkuda kõrgkoolide juhtkondadele tuge tõenduspõhiste muudatuste tegemisel.

Uuringu valimi moodustasid kümme kõrgkooli, mis olid 2014. aasta juuniks positiivselt akrediteeritud. Analüüsi tulemused osutasid, et kõrgkoolid on edukad personali- ja ressursijuhtimises, nende taristu on väga heal tasemel ning üldjuhul on kõrgkoolide lõpetajad konkurentsivõimelised nii Eestis kui ka rahvusvaheliselt. Uuringust ilmnes ka selge vajadus kõrgkoolide tegevust fookustada, arendada piiratud ressursi tingimustes neid valdkondi, milles ollakse tugevad, ning loobuda valdkondadest, kus puudub kriitiline hulk üliõpilasi ja/või heal tasemel õppejõude. Vaja on muuta kõrgkoolis õppimise ja õpetamise paradigmat, liikudes traditsioonilise õppejõu- ja ainekeskse õpetamise juurest iga õppija individuaalset ja sotsiaalset arengut toetava koostöise õppimise ja õpetamise suunas. Eesti kõrghariduse kestlikkuse seisukohast on samuti oluline lisada rahvusvaheline mõõde kõikidesse kõrgkooli põhiprotsessidesse, sh nendes kõrgkoolides, mis on orienteeritud ainult siseturule.
\end{abstract}

Võtmesõnad: kõrgkoolid, institutsionaalne akrediteerimine, strateegiline juhtimine, hindamisvaldkond

1 Eesti Kõrghariduse Kvaliteediagentuur, SA Archimedes, Toompuiestee 30, 10149 Tallinn; maiki.udam@archimedes.ee 


\section{Sissejuhatus}

Väga tihti on kõrgkoolide juhtimise otsused ja nendest johtuvad organisatsioonisisesed arengusuundumused põhjustatud välistest teguritest, näiteks mõjutavad kõrgkoolide tegevust muudatused seadustes, aga ka välishindamisest saadud tagasiside (Carr, Hamilton, \& Meade, 2005). Eestis oli aastatel 1997-2010 peamiseks välishindamise meetodiks õppekavade akrediteerimine. Kuna üksikute õppekavade akrediteerimise mõju kõrgkoolide juhtimisele ja toimimisele oli tagasihoidlik (Vilgats, 2009) ning kogu protsess oli äärmiselt töö- ja ressursimahukas nii hinnatavatele kui ka hindajatele, otsustati 2010. aastal üle minna institutsiooni kui terviku hindamisele (Riigikogu, 1995). Sarnast arengut, kus õppekavade akrediteerimine asendatakse institutsionaalse hindamisega, võib täheldada kogu Euroopas (Westerheijden, Stensaker, \& Rosa, 2007; Williams, 2009).

Institutsionaalse hindamise eesmärgid on eri riikides küllaltki sarnased: hariduse kvaliteedi parendamine ja avaliku informatsiooni pakkumine selle kohta, kas hariduse kvaliteet vastab nõuetele (Hämäläinen, Mustonen, \& Holm, 2004). Eestis on institutsionaalse akrediteerimise peamine eesmärk toetada kõrgkoolide strateegilist juhtimist (Institutsionaalse akrediteerimise ..., 2011), kuna eestvedamise - st juhtimise - kvaliteedist sõltub otseselt kogu organisatsiooni käekäik (Oakland, 1996). Teisteks eesmärkideks on huvigruppide teavitamine kõrgkooli põhitegevuste tulemustest ning Eesti kõrghariduse usaldusväärsuse ja konkurentsivõime suurendamine (Institutsionaalse akrediteerimise ..., 2011).

Akrediteerimisprotsess on Eestis üles ehitatud kooskõlas akrediteerimise hea tavaga: defineeritud on standardid, kusjuures kirjeldatud on miinimumnõudeid ja esitatud hea tava näiteid; akrediteerimine sisaldab hindamiskülastust; akrediteerimiseksperdid on hinnatava kõrgkooli sarnase kõrgkooli juhid, üliõpilased ja tööandjad. Hindajateks on peamiselt tunnustatud eksperdid väljastpoolt Eestit. Nende koostatud hindamisaruanne on mahukas dokument, mis käsitleb mitmeid organisatsiooni seisukohast olulisi valdkondi: organisatsiooni juhtimist ja toimimist; õppetegevust; teadus-, arendus- ja/või muud loometegevust (TAL) ning ühiskonna teenimist. Institutsionaalse akrediteerimise aruande täpsema struktuuriga saab tutvuda lisas 1.

Kõrgkool võib saada akrediteeringu seitsmeks aastaks (vajaduse korral tingimuslikult) või kolmeks aastaks (suuremate puuduste korral), oluliste vajakajäämiste puhul on võimalik kõrgkool akrediteeringust ilma jätta (Institutsionaalse akrediteerimise ..., 2011). Esimese institutsionaalse akrediteerimise tegi Eesti Kõrghariduse Kvaliteediagentuur (EKKA) 2011. aastal. 
2014. aasta suveks olid akrediteeritud pooled kõrgkoolid - 23 institutsioonist 11, sh kaks avalik-õiguslikku ülikooli, üks eraülikool, viis riigi rakenduskõrgkooli ja kaks erarakenduskõrgkooli ${ }^{2}$. Seega on just praegu õige aeg teha vahekokkuvõte.

Artikkel põhineb 2014. aastal EKKAs läbi viidud hindamisraportite analüüsil ${ }^{3}$, mille eesmärk oli välja selgitada Eesti kõrgkoolide peamised tugevad ja nõrgad küljed ning teha võimaluse korral üldistusi Eesti kõrghariduse kui terviku, samuti eraldi kõrgkoolitüüpide (rakenduskõrgkool $v s$. ülikool) kohta. Uurimisküsimused olid järgmised: a) millistele institutsionaalse akrediteerimise alateemadele/hindamisvaldkondadele on eksperdid enam tähelepanu pööranud, neid oluliseks pidanud? b) millised hindamisvaldkonnad on kõrgkoolides väga heal või, vastupidi, arendamist vajaval tasemel? c) milliseid konkreetseid soovitusi on eksperdid välja pakkunud?

Artikli eesmärk ühtib institutsionaalse akrediteerimise eesmärgiga teavitada huvigruppe - kõrgkoolide juhtkonda, õppejõude, üliõpilasi, poliitikuid, tööandjaid jt - kõrgkoolide juhtimise ja toimimise analüüsi tulemustest. Kuivõrd EKKA on võtnud oma ülesandeks kõrgkoolide arengu toetamise ning selleks vajaliku tagasiside andmise hindamisprotsessi kaudu, on akrediteerimisel peamine kasusaaja kõrgkooli juhtkond. Artiklis sisalduv informatsioon kolmeaastase hindamisperioodi üldistatud tulemuste, hindamiskomisjonide poolt oluliseks peetud väärtuste, arengusuundade ja parimate tavade kohta on hea taustamaterjal kõrgkooli positsioneerimisel ja edasise arengu kavandamisel. Tuvastatud tugevaid külgi saavad kõrgkoolide juhid soovi korral kasutada hea praktika näidetena ning välja toodud probleemid võiksid olla tähelepanu all kõikide kõrgkoolide enesehindamise protsessis. Samuti pakuvad alltoodud tulemused väärtuslikku teavet ülikoolidega sõlmitavate tulemuslepingute tarbeks ning peaksid andma poliitikutele ja haridusametnikele mõtlemisainet nt seadusandlike, struktuursete või rahastamissüsteemi muudatuste tegemiseks.

\section{Valim ja meetod}

Uuringu valimi moodustasid kõik 2014. aasta juuniks positiivselt akrediteeritud Eesti kõrgkoolid: kümme institutsiooni, sh kaks avalik-õiguslikku ülikooli, üks eraülikool, viis riigi rakenduskõrgkooli ja kaks erarakenduskõrgkooli. Tegemist oli kvalitatiivsel dokumendianalüüsil põhineva uuringuga,

2 http://ekka.archimedes.ee/korgkoolile/institutsionaalne-akrediteerimine/ajakava.

3 Sarnaseid uuringuid on korraldanud näiteks Suurbritannia kvaliteediagentuur (http://www. qaa.ac.uk/Publications/InformationAndGuidance/Documents/Outcomes-assessment.pdf), Eestis on see uuring esmakordne. 
mistõttu tegime sisuanalüüsi (summative content analysis), kus kõikide hindamisraportite tugevad ja nõrgad küljed klassifitseeritakse ja kodeeritakse.

Kuna uuringu eesmärgid on seotud enim väärtustatud valdkondade tuvastamise ja nendele antud hinnangutega, samuti varem kokku lepitud hindamisprotseduuriga, kasutasime kodeerimise esimeses faasis korraga mitut tüüpi kodeerimist: magnituudkodeerimist (magnitude coding), hinnangkodeerimist (evaluation coding), kirjeldavat kodeerimist (descriptive coding), hüpoteeskodeerimist (hypothesis coding) ja uurivat kodeerimist (exploratory coding) (Saldana, 2012). Magnituudkodeerimine on meetod, mis lisab andmetele numbri või muu info ning sobib kasutamiseks koos väärtuste ja hinnangute koodidega. Magnituudkodeerimine on üks viis andmeid kvantifitseerida ja see võimaldab kanda andmed koondtabelisse või maatriksisse, et neist oleks ülevaade. Hinnangkodeerimine on segu kahest kodeerimistüübist: magnituudkodeerimisest (näitab, kas vastaja esitas positiivse $(+)$ või negatiivse $(-)$ kommentaari) ja kirjeldavast kodeerimisest (näitab teemat) (Saldana, 2012). Andmete kodeerimise esimeses faasis kasutasime meetodina lisaks hüpoteeskodeerimist, mille puhul lähtusime eelmääratud koodidest (hindamisnõuetest), mis eeldatavalt võisid varasema teadmise põhjal andmetest ilmneda. Hüpoteeskodeerimine on andmete analüüsi segameetod (mixed method) ja seda kasutatakse sageli sisuanalüüsi korral (Saldana, 2012). Uurivat kodeerimist rakendati siinse uuringu esimeses faasis, st enne seda, kui töötati välja täpsem kodeerimissüsteem.

Infoajastul soovitatakse kvalitatiivse uuringu puhul kasutada arvutipõhist andmetöötlust (näiteks Microsoft Exceli ja Wordi tabelitena), kuid kvalitatiivsed andmed ei pruugi kajastada vaid eelmääratud tunnuseid ja võivad seega olla hoomamatud juhul, kui andmestik pole hästi organiseeritud (Hahn, 2008). Selleks, et saada andmetest esmast ülevaadet, kandsime Exceli tabeli tulpadesse koodidena kõik hindamisraporti hindamisvaldkonnad ja alavaldkonnad ning raporteid lugedes sisestasime andmetabeli ridadesse hindajate väited/hinnangud (arengusoovitused ja kiitused): 0 - „, arendamist vajav” ja 1 - „kiiduväärne” (vt lisa 2). Kandsime tabelisse vaid väga positiivsed ja selgelt kriitilised hinnangud. Tühjad lahtrid tabelis tähendavad, et seda valdkonda ei olnud eksperdid eraldi positiivselt või negatiivselt rõhutades välja toonud, mis tähendab seda, et need valdkonnad on tavapärasel tasemel ja/või praegu mitte kõige olulisemad või pakilisemad. Seega võimaldas kasutatud kodeerimissüsteem eristada iga hinnatud asutuse hinnatava alavaldkonna kolme taset („,arendamist vajav / väga oluline”; „, rahuldav, heal tasemel / praegu mitte kõige olulisem”; „väga heal tasemel, kiiduväärne / väga oluline"). 
Kandsime andmetabelisse ka muu info kõrgkoolide kohta (nimi, kõrgkooli tüüp jne). Kõik ekspertide hinnangud, mis ei sobinud väga täpselt hindamisraporti väidete alla, kodeerisime eraldi ning sisestasime Exceli tabelisse tulpadena, lisades juurde, kas antud hinnang oli kiitus (1) või arengusoovitus (0).

Selleks, et saada ülevaade, kui sageli olid eksperdid hindamisvormi alateemasid positiivses või negatiivses võtmes esile toonud, kasutasime andmete töötlemiseks SPSSi. Descriptive Statisticsi funktsioon võimaldas saada kohese ülevaate summeeritud andmetest ja selle põhjal koostada tabeli selle kohta, kui mitu korda oli nõude täitmist hinnatud kas kõrgelt või madalalt (vt lisa 3). Näiteks ilmneb punktist 1.1.2, et kuue kõrgkooli puhul oli hindamiskomisjon selle valdkonna kiitusega välja toonud ning selgelt negatiivses võtmes ei ole seda aspekti kordagi käsitletud. Samas tuleb arvestada, et hinnati kümmet kõrgkooli, seega nelja asutuse puhul pole hindajad seda nõuet täpselt sellises sõnastuses maininud. Tegu on kõrgkooli juhtimise ja toimimise seisukohast väga olulise aspektiga, mistõttu võib eeldada, et kõik komisjonid on seda oma aruannetes siiski erineva detailsusastmega käsitlenud, lähtudes iga konkreetse kõrgkooli spetsiifikast.

Andmetöötluse teisel ringil kandsime andmed NVivosse ja kodeerisime täpsemalt väited, mis ei sobitunud üheselt hindamisnõuete alla. Selles etapis kasutasime avatud kodeerimist (open coding) ja musterkodeerimist (pattern coding) (Saldana, 2012) ning eesmärk oli andmete põhjal leida olulised teemad ja avastada korduvusi või seaduspärasusi. Kolmanda ringi kodeerimine toimus samm-sammult üha täpsemate kategooriate ja teemade suunas. Hahn (2008) on väitnud, et tavaliselt on kvalitatiivseid andmeid vaja töödelda ja kodeerida vähemalt 3-4 sammuna. Nii toimisime ka praeguses uuringus.

\section{Tulemused}

Tulemuste tõlgendamisel tuleb lähtuda asjaolust, et kvalitatiivne uuring põhineb selles osalejate vaadetel ja kogemustel (Klenke, 2008). Praegusel juhul on osalejateks kümme rahvusvahelist hindamiskomisjoni, igas komisjonis 4-6 liiget eri riikidest ning erineva professionaalse taustaga. Willingi (2013) kohaselt sisaldab kvalitatiivne uuring alati interpretatsiooni. Interpretatsiooni ehk tähenduse otsimise kaudu püütakse selgitada uurimisobjekti aspekte või dimensioone, mis pole otseselt nähtavad (Willing, 2013). Kvalitatiivse uuringu fookus on situatsiooni mõistmisel ja kontekstist arusaamisel (Merriam, 2009) ning konteksti võtmine vaatluse alla on eriti oluline juhtimisteemaliste uuringute puhul (Klenke, 2008). Praegune uuring 
võimaldas saada ülevaate seni institutsionaalse akrediteerimise läbinud kõrgkoolide tugevatest ja nõrkadest külgedest ning leida läbivaid teemasid, märksõnu ja ideid, mis on kõrgkoolidele praegusajal Eesti kontekstis olulised. Enne tulemuste tõlgendamist tuleb aga veel kord osutada andmetest ja meetodist tulenevatele piirangutele.

Uuring võimaldas hästi kirjeldada teemavaldkondi, kus osa kõrgkoole on juba märkimisväärseid tulemusi saavutanud ja kuhu teised võiksid veelgi enam panustada. Samas ei võimalda uuringu andmestik määrata väga täpselt kindlaks nende saavutuste taset, kuna komisjonide hinnangud, mida kodeeriti, olid eristatavad kolmepalliskaalal („arendamist vajav / oluline”; „heal tasemel / praegu mitte nii oluline”; „väga heal tasemel / oluline”). Vaid mõne kõrgkooli puhul oli komisjon lisaks nimetanud valdkonna, mida suurepärasena esile tõsteti. Hindamisaruannetes kajastub see esiletõstmine märkes „tunnustust vääriv”.

Nii mõnigi kord oli komisjon hinnanud mõne valdkonna või alavaldkonna taseme väga heaks, juhtides samal ajal tähelepanu vajadusele, et valdkonna olulisuse ja/või keskkonnast tulenevate mõjude tõttu tuleb kõrgkoolil sellesse valdkonda veelgi enam panustada. Seega võis valdkonna / alavaldkonna / nõude täitmise tase olla teiste kõrgkoolidega ja indikatiivse rahvusvahelise tasemega võrreldes väga hea, kuid konkreetne komisjon võis siiski pidada vajalikuks juhtida kõrgkooli tähelepanu vajadusele keskenduda just selle aspekti arendamisele.

Peaaegu kõik hindamiskomisjonid (9 korral, sh 3 ülikooli ja 6 rakenduskõrgkooli) leidsid, et kõrgkoolid lähtuvad uute õppekavade väljatöötamisel tööturu vajadustest ja ühiskonna ootustest (vt tabel 1). Kuuel korral (sh 5 rakenduskõrgkooli) oli välja toodud, et kõrgkoolide arengu- ja tegevusplaanid on kooskõlas ja lähtuvad nende missioonist, visioonist ja põhiväärtustest ning arvestavad ühiskonna vajadustega. Samuti toodi korduvalt välja (6 korral, sh 5 rakenduskõrgkooli), et töötajate rahulolu juhtimise, töötingimuste, infoliikumise ja muuga uuritakse regulaarselt ning tulemusi kasutatakse parandustegevustes. Suurem osa hindamiskomisjonidest (6 komisjoni) leidis, et kõrgkoolide finantsressursside kasutamine, administreerimine ja taristu arendamine on lähtunud arengukavast ja ühiskonna vajadustest. Kõrgkoolid pakuvad kõrgetasemelist haridust, mis võimaldab lõpetajatel konkureerida nii riigisisesel kui ka rahvusvahelisel tööjõuturul (6 korral, sh 5 rakenduskõrgkooli), ning kasutavad õppetöö korraldamisel tänapäevaseid tehnilisi ja haridustehnoloogilisi vahendeid (6 korral, sh 5 rakenduskõrgkooli). Kõige rohkem arenguruumi leiti olevat seoses TALi arendamiseks vajalike rahaliste vahendite ja nende hankimist toetava strateegiaga (5 korral, sh 3 rakenduskõrgkooli). Juhtimise valdkonnas 
kritiseeriti kõige rohkem võtmetulemuste määratlemist (3 korral, sh 2 rakenduskõrgkooli), mis on osaliselt seotud vajakajäämistega TALi eesmärkide seadmisel ja nende mõõtmisel (4 korral, sh 3 rakenduskõrgkooli).

Tabel 1. Kõige rohkem/sagedamini kiituse või arengusoovitusena välja toodud hindamisnõuded (kokku vähemalt 5 korda)

\begin{tabular}{|c|c|c|}
\hline Hindamisnõue & $\begin{array}{l}\text { Kiitused } \\
\qquad\end{array}$ & $\begin{array}{l}\text { Arengu- } \\
\text { soovitused } \\
\quad N\end{array}$ \\
\hline $\begin{array}{l}\text { 1.1.2. Kõrgkooli arengukava ja sellega seonduvad tegevus- } \\
\text { kavad lähtuvad kõrgkooli missiooni, visiooni ja põhiväärtuste } \\
\text { alusel püstitatud ning riigi prioriteete ja ühiskonna ootusi } \\
\text { arvestavatest konkreetsetest eesmärkidest. }\end{array}$ & 6 & 0 \\
\hline 1.1.3. Määratletud on kõrgkooli võtmetulemused. & 2 & 3 \\
\hline $\begin{array}{l}\text { 1.1.4. Kõrgkooli arengukava ja tegevuskavade väljatöötamist } \\
\text { ja elluviimist juhib tippjuhtkond ning kaasab liikmeskonna ja } \\
\text { erinevad huvigrupid. }\end{array}$ & 5 & $\mathbf{0}$ \\
\hline $\begin{array}{l}\text { 1.1.5. Vastutus kõikidel juhtimistasanditel on määratletud ja } \\
\text { kirjeldatud ning toetab kõrgkooli eesmärkide saavutamist ja } \\
\text { põhiprotsesside sidusat toimimist. }\end{array}$ & 4 & 1 \\
\hline $\begin{array}{l}\text { 1.2.4. Töötajate rahulolu juhtimise, töötingimuste, infoliiku- } \\
\text { misega jne uuritakse regulaarselt ning tulemusi kasutatakse } \\
\text { parendustegevustes. }\end{array}$ & 6 & $\mathbf{0}$ \\
\hline $\begin{array}{l}\text { 1.3.1. Kõrgkooli rahaliste vahendite jaotus ning taristu halda- } \\
\text { mine ja arendamine on majanduslikult otstarbekas ning lähtub } \\
\text { kõrgkooli arengukava eesmärkidest ja riiklikest prioriteetidest } \\
\text { (v.a erakõrgkoolid). }\end{array}$ & 6 & 1 \\
\hline $\begin{array}{l}\text { 1.3.2. Kõrgkool kasutab infosüsteeme, mis toetavad kõrgkooli } \\
\text { juhtimist ja põhiprotsesside sidusat toimimist. }\end{array}$ & 5 & 1 \\
\hline $\begin{array}{l}\text { 1.3.3. Personali töötingimused ning üliõpilaste õppe- ja TAL } \\
\text { tingimused (raamatukogu, stuudiod, töökojad, laborid jne) } \\
\text { vastavad kõrgkooli spetsiifikast tulenevatele vajadustele ning } \\
\text { liikmeskonna ootustele. }\end{array}$ & 5 & $\mathbf{0}$ \\
\hline $\begin{array}{l}\text { 2.1.2. Kõrgkool loob eeldused oma lõpetajate konkurentsi- } \\
\text { võime tagamiseks nii siseriiklikult kui rahvusvaheliselt. }\end{array}$ & 6 & $\mathbf{0}$ \\
\hline $\begin{array}{l}\text { 2.2.1. Õppekavade avamisel lähtub kõrgkool oma eesmärkidest } \\
\text { ja tööturu vajadustest ning arvestab riigi strateegiate ja } \\
\text { ühiskonna ootustega. }\end{array}$ & 9 & 0 \\
\hline $\begin{array}{l}\text { 2.2.2. Õppekavade arendustegevused on süsteemsed ja } \\
\text { regulaarsed ning õppekavaarendusse kaasatakse erinevad } \\
\text { huvigrupid. }\end{array}$ & 5 & 2 \\
\hline
\end{tabular}




\begin{tabular}{l|c|c}
\hline Hindamisnõue & $\begin{array}{c}\text { Arengu- } \\
\text { Kiitused } \\
\text { soovitused } \\
\mathbf{N}\end{array}$ \\
\hline $\begin{array}{l}\text { 2.2.3. Uuritakse ja analüüsitakse vilistlaste rahulolu õppe } \\
\text { kvaliteediga ning tööandjate rahulolu lõpetajate tasemega ja } \\
\text { vastavusega tööturu nõuetele; tulemusi arvestatakse õppe- } \\
\text { kavaarenduses. }\end{array}$ & $\mathbf{3}$ & $\mathbf{3}$ \\
\hline $\begin{array}{l}\text { 2.3.1. Üliõpilaste akadeemilist edasijõudmist jälgitakse ja } \\
\text { toetatakse. }\end{array}$ & $\mathbf{4}$ & $\mathbf{1}$ \\
\hline $\begin{array}{l}\text { 2.3.3. Kõrgkoolis on toimiv varasemate õpingute ja töö- } \\
\text { kogemuse arvestamise süsteem. }\end{array}$ & $\mathbf{4}$ & $\mathbf{1}$ \\
\hline $\begin{array}{l}\text { 2.4.4. Õppetöö korraldamisel kasutatakse kaasaegseid tehnilisi } \\
\text { ja haridustehnoloogilisi vahendeid. }\end{array}$ & $\mathbf{6}$ & $\mathbf{1}$ \\
\hline $\begin{array}{l}\text { 3.1.1. Kõrgkool on TAL valdkonnas määratlenud eesmärgid ja } \\
\text { mõõdab nende täitmist. }\end{array}$ & $\mathbf{2}$ & $\mathbf{4}$ \\
\hline \begin{tabular}{l} 
3.2.1. Kõrgkoolis toimib TAL tugisüsteem. \\
\hline $\begin{array}{l}\text { 3.2.2. Kõrgkoolil on TALi arendamiseks vajalikud rahalised } \\
\text { vahendid ning nende hankimist toetav strateegia. }\end{array}$
\end{tabular} & $\mathbf{1}$ & $\mathbf{3}$ \\
\hline
\end{tabular}

Kõik sellised väited, mis ei sobitunud täpselt hindamisnõuetega ning mida ei saanud kohe summeerida, töödeldi NVivos ja kodeeriti, leidmaks korduvusi ja seaduspärasusi. Järgnevalt vaatlemegi eeltoodule lisaks teemasid, mida eksperdid on peale hindamisvormi alapunktide oluliseks pidanud, millele on nad detailselt tähelepanu pööranud ja mille kohta on nad esitanud ka arendusettepanekuid. Andmete põhjal ei olnud kõikide teemade puhul võimalik välja tuua selgeid erinevusi rakenduskõrgkoolide ja ülikoolide vahel. Komisjonide esitatud seisukohtade hulgas oli nii teemasid, mida oli mainitud vaid kord või kaks, kui ka teemasid, mis kordusid. Järgnevas tekstis on numbriliselt välja toodud need väited, mida eksperdid on nimetanud kolmel või enamal korral. Lisaks on osutatud nendele ekspertide tähelepanekutele, mida on küll mainitud üksikutel juhtudel, kuid mis võivad anda mõtlemisainet ka nende kõrgkoolide juhtidele, mille hindamisel ei ole eksperdid sellele aspektile tähelepanu pööranud.

\section{Ressursside juhtimine}

Üliõpilaste arvu vähenemine ja kõrgharidusreform, mis võimaldab kõikidel üliõpilastel saada eesti keeles tasuta kõrgharidust, ning peatselt lõppevad Euroopa Liidu toetusprogrammid on tekitanud uudse olukorra, millele ka eksperdid tähelepanu juhtisid. Seoses sellega on varasemast olulisem 
strateegiline juhtimine, mis lähtub selgelt seatud prioriteetidest (3 korral) ning olukorra ja andmete analüüsist (3 korral). On tarvis tasakaalustada kõrgkooli eelarve (3 korral) ning senisest enam tuleb keskenduda korraga nii kvaliteedile kui ka ökonoomsusele. Läbi tasub mõelda, mida teha ebapopulaarsete õppekavadega ja selliste õppekavadega, mis on saanud tähtajalise õppe õiguse. Mõistlik on kehtestada üliõpilaste miinimumarv, mis on organisatsiooni seisukohast asjakohane. Tuleks välja töötada selged plaanid, kuidas ka Euroopa tõukefondide toetuste lõppemisel oleks piisavalt rahalisi vahendeid, et uuendada soetatud aparatuuri ja hoida korras taristut. Ekspertide hinnangul on sellises olukorras väga oluline juhtkonna suutlikkus kaasata erinevaid osapooli kõrgkooli ees seisvatele probleemidele lahenduste leidmisse. Samas on vaja tõhustada otsustusprotsessi ning teha vajalikke ümberkorraldusi.

\section{Töötajad}

Hindamiseksperdid on kõrgkoolide töötajate suhtes olnud tunnustavad ning kiitnud kompetentset ja motiveeritud töötajaskonda (3 korral). Kuna kõrgkool peaks ise olema õppiv organisatsioon, siis kvaliteetse, kompetentse töötajaskonna olulisust ei saa alahinnata. Eksperdid on kiitnud Eesti kõrgkoolide organisatsioonikultuuri ning erinevaid vorme töötajate professionaalse arengu toetamisel (koolitused, mentorid, rotatsioon jm) (5 korral). Töötajatele tuleks selgitada organisatsiooni eesmärke, sest omaks võetud eesmärgid ja väärtused aitavad kaasa ka töötajate autonoomiatunde suurendamisele. Töötajate koolituste mõju tuleks regulaarselt hinnata. Töötajate motivatsiooni seisukohast on oluline tunnustada suurepärast tööd. Hindajad tõid välja, et juba praegu tuleks kavandada finantseerimisskeeme, mis ei sõltuks Euroopa Liidu tõukefondide toetusest (programm PRIMUS), tagamaks toetussüsteemide kestlikkust.

\section{Uute sihtrühmade leidmine}

Olukord Eesti kõrgharidusmaastikul on konkurentsitihe ja senisest enam on vaja mõelda läbi, kuidas säilitada üliõpilaste arvu. Hindamiskomisjonid juhtisid tähelepanu vajadusele leida uusi sihtrühmi (3 korral), mis võib tähendada eri vanuses õppijatele sobilike õppevormide rakendamist nii tasemeõppes kui ka täienduskoolituses. Kõrvuti rahvusvaheliste üliõpilastega peaksid kõrgkoolid enam arvestama vene keelt emakeelena kõnelevate kohalike õppijate võimaluste ja vajadustega. Kasuks tuleks turundustegevuse tõhustamine (3 korral) ja sihipärane kommunikatsioon erinevate huvipooltega, sh potentsiaalsed tööandjad ( 3 korral). Ebapiisavalt 
on seni kasutatud vilistlaskonna tuge kommunikatsiooni- ja turundustegevuses. Soovitatav on üle vaadata kõrgkooli vene- ja ingliskeelsed kodulehed, hinnates üksiti logode mõistetavust. Meediasuhtlust tuleks planeerida ja jälgida.

\section{Õppetöö}

Õppetöö kvaliteedi hoidmiseks tuleb ühtlustada õpiväljundid, mis ideaalis on selgelt sõnastatud ja saavutatavad (3 korral). Kokku tuleb leppida õppe eesmärkides ja meetodites ( 3 korral). Oluline on paindlik ja õppetööd toetav hindamine (4 korral). Peale kokkuvõtva hindamise tuleks õpiaja jooksul kasutada ka kujundavat hindamist.

Eksperdid on kiitnud kõrgetasemelist praktikakorraldust (4 korral) ja õppetöö praktilist suunitlust (rakenduskõrghariduses). Üliõpilaste tagasisidesüsteemid on küll ajakohased ja toimivad, kuid vajalik on, et info üliõpilaste tagasiside põhjal tehtud parenduste kohta jõuaks nii üliõpilaste kui ka hinnatud õppejõududeni. Positiivsena on eksperdid esile toonud õppejõudude töö tunnustamist iga-aastaste parimate õppejõudude premeerimise/ nimetamisega.

\section{Üliõpilaste väljalangevus}

Mitmete kõrgkoolide puhul on murekohaks üliõpilaste suur väljalangevus õppeaja jooksul (6 korral). See probleem on päevakorral kõikidel õppetasemetel, kaasa arvatud doktoriõpe (2 ülikooli). Kuna üliõpilaste arv on niigi kahanemas, on suur vajadus pöörata tähelepanu väljalangemisohus üliõpilaste varasele märkamisele ( 3 korral) ja üliõpilaste õppetöö toetamisele. Erivajadustega üliõpilaste õppetöö eeskirjad tasub üle vaadata (3 korral). Majanduslikel kaalutlustel paljud üliõpilased töötavad ning seega võib olla abiks varasemate õpingute ja töökogemuse arvestamise (VÕTA) süsteem, mida tasub üliõpilastele senisest rohkem selgitada.

Kuna paljud üliõpilased jätavad õpingud pooleli lõputöö kirjutamise faasis, tuleb pöörata tähelepanu lõputööde juhendamisele. Üliõpilaste rahulolu lõputööde juhendamisega on oluline ja seega tuleks kindlasti koguda andmeid juhendamise kvaliteedi kohta. Abi võiks olla ka juhendajate koolitamisest ning ühe sise- ja ühe välisjuhendaja määramisest. 


\section{Teadus-, arendus- ja loometegevus (TAL)}

TALiga seoses on arendamist vajavaid valdkondi paljudel kõrgkoolidel, eriti rakenduskõrgkoolidel. Enim (3 korral) oli rakenduskõrgkoolidel probleeme TALi arendamiseks vajalike rahaliste vahendite ning nende hankimist toetava strateegia nõude täitmisega (vt ka tabel 1, punkt 3.2.2). Mitmel kõrgkoolil oleks vaja selgemat TALi strateegiat (4 korral). Läbi tuleks mõelda, mida kõrgkool teadus- ja arendustegevuse all mõistab (3 korral) - see kehtib eriti rakenduskõrgkoolide kohta. Samuti tuleb kindlaks määrata, mis suundades on organisatsioon valmis uuringuid korraldama. Rakenduskõrgkoolidel on vaja luua mõistlik sammsammuline plaan, et arendada rakendusuuringuid. Õppejõude tuleks julgustada arendama uurimistööks vajalikke oskusi. Võib mõelda mentorprogrammide loomisele teadustöö toetamiseks viisil, millega toetatakse õppetööd. Välja tuleks töötada põhimõtted, kuidas parandada teadustöö kvaliteeti, mitte ainult suurendada avaldatud artiklite arvu. Kasuks tuleks tööandjate kaasamine uuringutesse.

Eraldi teema on õppejõudude koormuse arvestus, mis peab tagama piisava ajaressursi selleks, et tegelda teadustööga (4 korral). Vajalik on ka rahaliste lisavahendite eraldamine, et õppejõud saaksid teha teadustööd ja mõistlikes piirides uuringutega seoses välislähetustes viibida. Senisest enam on vaja rõhutada akadeemilise eetika olulisust ning kasutada plagiaadituvastusprogramme (4 korral) ja selgitada ebaeetilise teadustööga kaasnevaid tagajärgi.

\section{Rahvusvahelistumine}

Rahvusvahelistumine on teema, mida ühel või teisel moel rõhutasid kõik hindamiskomisjonid. Rahvusvahelistumise aktiivsus on praegu piisav vaid mõnes suuremas kõrgkoolis, ülejäänud kõrgkoolidel on veel palju arenguruumi. Rahvusvahelistumise eesmärke ja üliõpilaste mobiilsusega seonduvaid kitsaskohti tuleks käsitleda ka kõrgkooli arengukavas (6 korral).

Rahvusvahelistumine võib vajada sellega tegeleva osakonna loomist. Võib mõelda ka eraldi prorektori ametikohale, selmet käsitleda rahvusvahelistumist kõikides organisatsiooni osades eraldi. On tarvis välja töötada rahvusvahelistumise strateegia, et osaleda ühisprojektides väliskõrgkoolidega (4 korral) ja rahvusvahelistes teadusprojektides. Igati tuleks toetada rahvusvahelistes võrgustikes osalemist ja rahvusvaheliste meeskondade moodustamist. Laiendada tuleb külalisprofessorite vahetust ja lühiajalisi mõlemasuunalisi töötajate vahetusi kõrgkoolide vahel. Soovitatav on välismaa teadlaste kaasamine õppe- ja teadustöösse ning doktoritööde juhendamisse ja retsenseerimisse (3 korral). 
Üliõpilasvahetuse korraldamiseks on oluline üle vaadata õppetöö korraldus, kasutada õppetöös enam inglise keelt ning pakkuda ingliskeelseid valikained (6 korral). Soodustada tuleb ka eesti üliõpilaste mobiilsust (4 korral), võimaldades välismaal läbitud õppeaineid paindlikult üle kanda. Ka kõrgkoolide administratiivtöötajate välislähetusi tuleks toetada.

Eeltoodud teemadele lisaks tõid eksperdid 6 korral olulise aspektina välja, et kvaliteedi tagamine peaks olema enam nähtav ja ühtviisi tulemuslik igas valdkonnas ning rohkem integreeritud igapäevasesse töösse.

\section{Arutelu ja järeldused}

Vaadeldes komisjonide esiletõstmisi (kiitusi) ja soovitusi hindamisnõuete kaupa (vt tabel 1), ilmneb, et enim on komisjonid oma aruannetes osutanud kahele valdkonnale: organisatsiooni juhtimisele ja toimimisele (38 kiitust ja 6 soovitust) ning õppetegevusele (37 kiitust ja 8 soovitust). Organisatsiooni juhtimine on ka ainus valdkond, milles kaks kõrgkooli osutusid hindamise tulemusel tunnustust väärivaks. Seejuures puudutab õppetegevuse valdkonnas 8 soovitusest 5 ülikoole. Muus ülikoolide ja rakenduskõrgkoolide vahel valdkonniti suuri erinevusi ei ole.

TALi valdkonnas on komisjonide tähelepanekuid summaarselt küll vähem, kuid erinevalt kahest esimesest valdkonnast prevaleerivad siin arengusoovitused (5 kiitust ja 12 soovitust). Kui õppetegevuses anti enamik soovitustest ülikoolidele, siis TALi valdkonnas on just rakenduskõrgkoolidel vaja lähiaastatel lahendada mitmesuguseid keerulisi olukordi (8 soovitust). Samas on komisjonide hinnang ka ülikoolide suunal pigem kriitiline kui tunnustav (0 kiitust ja 4 soovitust).

Ühiskonna teenimine ei ole hindamisraportite hinnangute ja ekspertide väidete analüüsi põhjal otsustades kõrgkoolide jaoks strateegilise tähtsusega valdkond. Üksikuid esiletõsteid esines, samuti viiteid arenguvajadustele, kuid nende põhjal ei ole võimalik teha üldistusi. Ühiskonna teenimine on osa nõuete kaudu integreeritud ka teistesse valdkondadesse, mistõttu selle väljatoomine eraldi valdkonnana ei pruugi olla asjakohane. Pigem tõuseb hindamisaruannete detailse analüüsi põhjal (alajaotised 3.1-3.7) eraldi valdkonnana selgelt esile rahvusvahelistumine (3.7). Sama moodi nagu ühiskonna teenimine, on ka rahvusvahelistumine kõrgkoolide põhiprotsesse läbiv teema ning see joonistub Eesti demograafilist konteksti, kõrghariduse globaliseerumist ja Eesti ressursside piiratust arvestades reljeefselt ja suveräänselt välja. Märgilise tähendusega on ühe komisjoni soovitus kaaluda eraldi rahvusvahelistumise prorektori ametikoha (taas)loomist ülikoolis. See 
viitab ilmselt vajadusele eristada rahvusvahelistumise valdkonda ka institutsionaalse akrediteerimise nõuetes või käivitada temaatiline hindamine selles valdkonnas, mis on Eesti kõrghariduse jaoks eksistentsiaalse tähtsusega.

Toetudes tehtud analüüsi mõlema etapi tulemustele, võib nimetada mitmeid tugevaid külgi, mis iseloomustavad Eesti kõrgkoole.

1. Kõrgkoolide arengu kavandamine on sisukas, põhineb missioonil ja visioonil ning selles arvestatakse Eesti riigi prioriteetidega.

2. Tippjuhtkond kannab välja liidrirolli, liikmeskonna kaasamine otsustusprotsessi on heal tasemel.

3. Kõrgkoolid korraldavad töötajate rahuloluküsitlusi, saadud tagasisidet analüüsitakse, tulemustest informeeritakse liikmeskonda ning neid kasutatakse arendustegevustes.

4. Töötajate professionaalset arengut toetatakse erinevates vormides, areng on intensiivistunud suuresti tänu Euroopa Liidu tõukefondidele.

5. Rahaliste vahendite jaotus ja finantsjuhtimine on kooskõlas arengukavaga.

6. Kõrgkoolide taristu on eeskujulik, selle arenduses on arvestatud prioriteetsete suundadega.

7. Õppekavade avamisel lähtub kõrgkool oma strateegilistest eesmärkidest, arvestades samas tööturu vajaduste ja ühiskonna ootustega.

8. Praktikakorraldus on läbi mõeldud, rakenduskõrghariduses on õppetöös selgelt praktiline suunitlus.

9. Levinud on erinevate infotehnoloogiliste vahendite kasutamine õppetöös.

10. Eesti kõrgkoolide lõpetajad on konkurentsivõimelised nii sise- kui ka välisturul.

Samas tõid eksperdid välja mitmeid Eesti kõrghariduse kestlikkuse seisukohast kriitilise tähtsusega parendusvaldkondi/ettepanekuid.

1. Üldjuhtimine

- Keskenduda kõrgkooli tugevatele külgedele, määrata kindlaks võtmevaldkonnad ning suunata ressursid nende arendamisse

- Leida mõistlik ja edasiviiv tasakaal kvaliteedi ja ökonoomsuse (tõhususe) vahel kõikides oma tegevustes

- Viia otsusekindlalt ellu struktuursed muudatused, mis aitavad kõrgkoolil kohaneda keskkonna mõjudega ning mis toetavad tugevate külgede väljaarendamist nii õppetegevuse kui ka TALi valdkonnas

- Kaasata vilistlaskond kõrgkooli eesmärkide täitmisse (sh turundustegevusse), sidudes neid erinevate koostöövormide kaudu ning pakkudes võimalusi enesetäiendamiseks 


\section{Ressursside juhtimine}

- Maandada õppijate arvu vähenemisest tulenevaid finantsriske, mitmekesistades kõrgkooli tulubaasi

- Tagada aparatuuri uuendamine ja taristu korrashoid ka pärast Euroopa Liidu tõukefondide perioodi lõppu

- Sulgeda õppekavad, millel üliõpilaste arv jääb allapoole majandamispiiri ja/või mis ei kuulu kõrgkooli põhivaldkondadesse

3. Õppejõudude ja teadurite professionaalse arengu toetamine

- Valida oma õppejõudude ja teadurite hulka parimatest parimad, võimaldades neile tulemusliku töö eest väärilist tasu ning tagades õppe- ja teadustöö koormuse mõistlik jagunemine

- Luua kõikidele õppejõududele stažeerimisvõimalus nii õppe- kui ka teadustöö vallas, hinnates muu hulgas selle mõju

- Pakkuda õppejõududele võimalusi arendada uurimistööks vajalikke oskusi ning tagada mõistliku koormusearvestuse kaudu teadustööks vajalik ajaressurss

- Tagada vahendid töötajate professionaalse arengu toetamiseks ka pärast Euroopa Liidu tõukefondide perioodi lõppu

\section{4. Õppetegevus}

- Lõpetada tegevus nendes õppesuundades, kus puudub kriitiline hulk heal tasemel õppejõude

- Motiveerida õppejõude õppetööd ühiselt eesmärgistama ning metoodiliselt läbi mõtlema

- Vähendada väljalangevust, lähenedes igale õppijale individuaalselt ning pakkudes varakult tuge, mis arvestab tema võimete ja erivajadustega (nii füüsiliste kui ka hariduslike erivajadustega)

- Rakendada õppeprotsessis enam kujundavat hindamist, andes üliõpilastele sisukat tagasisidet õpitulemuste kohta ning suurendades seega nende õpimotivatsiooni

- Tagada üliõpilastele kvaliteetne juhendamine lõputööde kirjutamisel kõikidel õppeastmetel, küsides lõpetajatelt tagasisidet juhendamise kohta ning kasutades tulemusi arendustegevustes ja arenguvestlustes õppejõududega

- Pakkuda paindlikke võimalusi elukestvaks õppeks erinevatele earühmadele nii taseme- kui ka täiendõppes

- Arendada sisulist koostööd ettevõtlusega, kaasates praktikuid nii õppetöösse kui ka õppekavaarendusse 
5. Teadus- ja arendustegevus

- Kavandada TALi strateegia, mis lähtub kõrgkooli spetsiifikast ja tugevatest külgedest ning seab konkreetsed ja realistlikud eesmärgid lähiaastateks

- Keskenduda kvantiteedi asemel kvaliteedile

- Kaasata uuringute kavandamisse ja läbiviimisse tööandjaid

6. Rahvusvahelistumine

- Integreerida rahvusvaheline mõõde kõikidesse kõrgkooli põhiprotsessidesse, sh nendes kõrgkoolides, mis on orienteeritud ainult siseturule

- Arendada töötajate inglise keele oskust

- Pakkuda üliõpilastele valikaineid ja mooduleid inglise keeles

- Kutsuda välisõppejõude ning suunata oma õppejõud end väliskõrgkoolide juurde täiendama

- Osaleda rahvusvahelistes teadusprojektides ning kaasata väliskülalisõppejõude lõputööde hindamisse

- Suurendada üliõpilaste rahvusvahelist mobiilsust, muutes välisõpingute arvestamise kodukõrgkoolis paindlikuks ning õpingute lõpetamise nominaalajaga võimalikuks

Eesti kõrghariduse suurim väljakutse lähiaastatel on fookustada oma tegevust, st keskenduda kvantiteedi asemel kvaliteedile. Kõrghariduse ekspansiivse arengu periood Eestis on saanud paratamatult läbi, ümberorienteerumine intensiivsele arengule on vaevarikas ja stressirohke ning nõuab kõrgkoolide juhtimisel julgust võtta vastu ebapopulaarseid otsuseid.

Teine oluline väljakutse on seotud vajadusega muuta kõrgkoolis õppimise ja õpetamise paradigmat. Traditsioonilist auditoorset õppejõu- ja ainekeskset õpetamist peab asendama iga õppija individuaalse ja sotsiaalse arengu toetamisele orienteeritud koostöine õppimine ja õpetamine, mis on prioriteedina välja toodud ka „Eesti elukestva õppe strateegias 2020” (Eesti elukestva õppe ..., 2014).

Kui võrrelda praeguse uuringu tulemusi sissejuhatuses mainitud Suurbritannia kvaliteediagentuuri viimase uuringuga (Thematic Report ..., 2013), siis võib näha mitmeid sarnasusi, mis viitavad kõrghariduse ees seisvate ülesannete globaalsele iseloomule. Samamoodi nagu Eestis, toodi ka Suurbritannias rohkem kui ühe kõrgkooli puhul tugevate külgedena välja lõpetajate konkurentsivõimelisust, õppejõudude ja teiste töötajate professionaalse arengu toetamist, õppekavade arendamist ning kõrgkooli arengu kavandamist. Lisaks nimetati positiivsena üliõpilaste nõustamist. Kattuvad parandusvaldkonnad on institutsiooni strateegiate rakendamise variatiivsus kõrgkooli sees (Eestis: fookustamine, ühtlase kvaliteedi tagamine kõikides 
kõrgkooli allüksustes), üliõpilaste õppimist toetava hindamise arendamine ja rakendamine, üliõpilaste personaalne juhendamine, üliõpilaste ja õppejõudude mobiilsuse suurendamine. Parandada tuleks ka toetusskeemide rakendamist õpetavatele doktorantidele ning kõrgkoolisiseste andmete kogumist ja analüüsi.

Uuringu tulemused annavad Eestis esimest korda kõrgkoolide juhtkondadele ja ka poliitikutele/haridusametnikele n-ö tõenduspõhise lähtealuse tulevikuotsuste kujundamiseks. Kuigi sarnaseid uuringuid ei ole Eestis varem tehtud, võimaldab saadud andmestik edaspidi teha võrdlusanalüüse teiste kvaliteedihindamist käsitlevate teadustööde tulemustega, näiteks võrrelda erinevate huvigruppide ootusi (Udam, 2013; Udam \& Heidmets, 2013) ja tegelikku olukorda.

\section{Kasutatud kirjandus}

Carr, S., Hamilton, E., \& Meade, P. (2005). Is it possible? Investigating the influence of external quality audit on university performance. Quality in Higher Education, 11(3), 195-211. http://www.wallacefoundation.org/knowledge-center/school-leadership/ key-research/Documents/How-Leadership-Influences-Student-Learning.pdf.

Eesti elukestva õppe strateegia 2020 (2014). Külastatud aadressil http://hm.ee/sites/default/files/strateegia2020.pdf.

Hahn, C. (2008). Doing qualitative research using your computer: A practical guide. London: Sage.

Hämäläinen, K., Mustonen, K., \& Holm, K. (2004). Standards, criteria, and indicators in programme accreditation and evaluation in Western Europe. In L. Vlasceanu \& L. C. Barrows (Eds.), Indicators for institutional and programme accreditation in higher/tertiary education (pp. 17-32). Bucharest: UNESCO. Retrieved from www.cepes.ro/publications/pdf/Indicators.pdf.

Institutsionaalse akrediteerimise tingimused ja kord (2011). Külastatud aadressil http://ekka.archimedes.ee/files/IA_kord_14-1.pdf.

Klenke, K. (2008). Qualitative research in the study of the leadership. Bringely: Emerald Group Publishing.

Merriam, S. B. (2009). Qualitative research: A guide to design and implementation. San Francisco: John Wiley \& Sons.

Oakland, J. S. (1996). Total quality management: Text with cases. Oxford: Elsevier.

Riigikogu (1995). Ülikooliseadus. Riigi Teataja I 1995, 12, 119. Külastatud aadressil https://www.riigiteataja.ee/akt/110072012028.

Saldana, J. (2012). The coding manual for qualitative research (2nd ed.). London: Sage.

Thematic report on the outcomes of enhancement-led institutional reviews (ELIRs) conducted in 2013 (2013). Retrieved from http://www.qaa.ac.uk/en/Publications/Documents/Thematic-Report-Outcomes-of-ELIR-14.pdf.

Udam, M. (2013). Meeting state, market and academic concerns: Challenges for external quality assurance of higher education institutions. Estonian case (Doctoral dissertation). Tallinn: Tallinn University. Retrieved from http://e-ait.tlulib.ee/334/1/udam_maiki.pdf. 
Udam, M., \& Heidmets, M. (2013). Conflicting views on quality: Interpretations of 'a good university' by representatives of the state, the market and academia. Quality in Higher Education, 19(2), 210-224. doi: http://dx.doi.org/10.1080/13538322.2013.774805

Vilgats, B. (2009). Välise kvaliteedihindamise mõju ülikoolile: Eesti kogemuse analüüs. Tallinn: Tallinna Ülikool.

Westerheijden, D. F., Stensaker, B., \& Rosa, M. J. (Eds.) (2007). Quality assurance in higher education: Trends in regulation, translation and transformation. Dordrecht: Springer. doi: http://dx.doi.org/10.1007/978-1-4020-6012-0

Williams, P. (2009). The result of intelligent effort: Two decades in the quality assurance of higher education. London: University of London.

Willing, C. (2013). Introducing qualitative research in psychology (3rd ed.). New York: Open University Press. 


\section{Lisa 1}

Institutsionaalse akrediteerimise aruande struktuur

Institutsionaalse akrediteerimise käigus hinnatakse kõrgkooli juhtimist ja põhiprotsesse, mis on jagatud nelja suurde valdkonda ning mille all on omakorda alavaldkonnad (Institutsionaalse akrediteerimise ..., 2011).

1. Organisatsiooni juhtimine ja toimimine

1.1. Üldjuhtimine

1.2. Personalijuhtimine

1.3. Rahaliste vahendite ja taristu juhtimine

2. Õppetegevus

2.1. Õppetegevuse tulemuslikkus ja üliõpilaskonna kujunemine

2.2. Oppekavaarendus

2.3. Üliõpilaste akadeemiline edasijõudmine ja hindamine

2.4. Õppimise tugiprotsessid

3. Teadus-, arendus- ja/või muu loometegevus (TAL)

3.1. TAL tulemuslikkus

3.2. TAL ressursid ja tugiprotsessid

3.3. Üliõpilastööde juhendamine ja doktoriõpe

4. Ühiskonna teenimine

4.1. Kõrgkooli põhitegevuste populariseerimine ja kõrgkooli osalus ühiskondlikus arendustöös

4.2. Täienduskoolitus ja muu laiemale avalikkusele suunatud õppetegevus

4.3. Muu avalikkusele suunatud tegevus

Iga alavaldkonna juures on 2-5 konkreetset nõuet, mille täitmist komisjon hindab. 


\section{Lisa 2}

Näide Microsoft Exceli abil tehtud esimese ringi kodeerimise kohta (alavaldkond 1.1 „Üldjuhtimine”)

\begin{tabular}{|c|c|c|c|}
\hline \multirow[t]{3}{*}{$\begin{array}{l}\text { 1.1.2. Kõrgkooli } \\
\text { arengukava ja sellega } \\
\text { seonduvad tegevus- } \\
\text { kavad lähtuvad } \\
\text { kõrgkooli missiooni, } \\
\text { visiooni ja põhiväär- } \\
\text { tuste alusel püstitatud } \\
\text { ning riigi priori- } \\
\text { teete ja ühiskonna } \\
\text { ootusi arvestavatest } \\
\text { konkreetsetest ees- } \\
\text { märkidest. }\end{array}$} & $\begin{array}{l}\text { 1.1.3. Määrat- } \\
\text { letud on kõrg- } \\
\text { kooli võtme- } \\
\text { tulemused. }\end{array}$ & $\begin{array}{l}\text { 1.1.4. Kõrgkooli } \\
\text { arengukava ja } \\
\text { tegevuskavade } \\
\text { väljatöötamist ja } \\
\text { elluviimist juhib } \\
\text { tippjuhtkond ning } \\
\text { kaasab liikmes- } \\
\text { konna ja erinevad } \\
\text { huvigrupid. }\end{array}$ & $\begin{array}{l}\text { 1.1.5. Vastutus } \\
\text { kõikidel juhtimis- } \\
\text { tasanditel on määrat- } \\
\text { letud ja kirjeldatud } \\
\text { ning toetab kõrg- } \\
\text { kooli eesmärkide } \\
\text { saavutamist ja põhi- } \\
\text { protsesside sidusat } \\
\text { toimimist. }\end{array}$ \\
\hline & 0 & & \\
\hline & & 1 & \\
\hline 1 & 1 & & 1 \\
\hline \multirow[t]{2}{*}{1} & 1 & 1 & \\
\hline & 0 & 1 & \\
\hline 1 & & 1 & 0 \\
\hline \multirow[t]{2}{*}{1} & & 1 & 1 \\
\hline & 0 & & 1 \\
\hline 1 & & & 1 \\
\hline 1 & & & \\
\hline
\end{tabular}




\section{Lisa 3}

Näide SPSS Descriptive Statisticsi abil koostatud tabeli kohta. Positiivsete hinnangute (kiituste) ja negatiivsete hinnangute (arengusoovituste) arv

\begin{tabular}{|l|c|c|}
\hline 1.1. Üldjuhtimine & $\begin{array}{c}\text { Kiitused } \\
N\end{array}$ & $\begin{array}{c}\text { Arengu- } \\
\text { soovitused } \\
N\end{array}$ \\
\hline 1.1.1. Kõrgkool on määratlenud oma rolli Eesti ühiskonnas. & 2 & 0 \\
\hline $\begin{array}{l}\text { 1.1.2. Kõrgkooli arengukava ja sellega seonduvad } \\
\text { tegevuskavad lähtuvad kõrgkooli missiooni, visiooni ja } \\
\text { põhiväärtuste alusel püstitatud ning riigi prioriteete ja ühis- } \\
\text { konna ootusi arvestavatest konkreetsetest eesmärkidest. }\end{array}$ & 6 & 0 \\
\hline $\begin{array}{l}\text { 1.1.3. Määratletud on kõrgkooli võtmetulemused. } \\
\text { 1.1.4. Kõrgkooli arengukava ja tegevuskavade välja- } \\
\text { töötamist ja elluviimist juhib tippjuhtkond ning } \\
\text { kaasab liikmeskonna ja erinevad huvigrupid. }\end{array}$ & 2 & 3 \\
\hline $\begin{array}{l}\text { 1.1.5. Vastutus kõikidel juhtimistasanditel on määratletud ja } \\
\text { kirjeldatud ning toetab kõrgkooli eesmärkide saavutamist } \\
\text { ja põhiprotsesside sidusat toimimist. }\end{array}$ & 4 & 1 \\
\hline
\end{tabular}




\title{
Estonian higher education in the light of institutional accreditation or what managers should know
}

\author{
Maiki Udama1, Riin Seema $^{a}$, Heli Mattisen ${ }^{\text {a }}$ \\ a Archimedes Foundation, the Estonian Higher Education Quality Agency
}

\begin{abstract}
Summary
Management decisions in institutions of higher education and the resulting organisational developments are very often triggered by external factors for example, the activities of such institutions are influenced by changes in legislation, as well as by a feedback received in the course of external evaluations (Carr, Hamilton, \& Meade, 2005).

As the well-being of the entire organisation depends directly on leadership i.e. management (Oakland, 1996) the institutional accreditation which main aim is to support the strategic management of institutions of higher education has been the main model for external evaluation in Estonia since 2010. Informing interest groups about the results of the main activities of the institution and increasing the reliability and competitiveness of Estonian higher education (Institutsionaalse akrediteerimise ..., 2011) have been among other important goals.

This article is based on the analysis of evaluation reports conducted by the Estonian Higher Education Quality Agency (EKKA) in 2014 with the aim to map the main strengths and weaknesses of higher education institutions in Estonia and, where possible, to generalise Estonian higher education as a whole, as well as various types of institutions of higher education (universities $v s$ professional higher education institutions).

The research questions were as follows:

1. Which subtopics/areas of assessment of institutional accreditation have received the most attention from experts, i.e. which do they consider most important?

2. Which areas of assessment are at a very good level in higher education institutions and vice versa, which require further development?

3. What specific suggestions have the experts made?
\end{abstract}

1 Estonian Higher Education Quality Agency, Archimedes Foundation, Toompuiestee 30, 10149 Tallinn, Estonia; maiki.udam@archimedes.ee 
The goal of this article matches the goal of institutional accreditation: to inform interest groups - the management boards of such institutions, lecturers, students, politicians and employers - of the results of the managing and functioning of institutions. As the EKKA has declared that its mission is to support the development of higher education institutions and provide the necessary feedback via the assessment process, the main beneficiaries of the accreditation are the management boards of institutions. The managers of institutions of higher education can use mapped strengths as examples of good practice if they wish and the highlighted problems can form the centre of attention in the self-evaluation process of all institutions of higher education. The results below also represent valuable input for performance agreements and should provide politicians and educational officials with food for thought in terms of e.g. changes in legislation, structure or funding systems.

The sample for the research was formed of all Estonian institutions of higher education that had been positively accredited by June 2014: 10 institutions, including two universities in public law, one private university, five state professional higher education institutions and two private professional higher education institutions.

This was a qualitative survey, based on document analysis, which is why we used summative content analysis as the research method, wherein all strengths and areas of improvement mentioned in assessment reports are classified and coded.

Nearly all assessment committees found that institutions of higher education are guided by the needs of the labour market and the expectations of society when developing new study programmes. In six cases, it was highlighted that the development and action plans of the institutions matched and were based on their missions, visions and basic values, as well as taking the needs of society into consideration. It was also repeatedly highlighted that the satisfaction of employees with management, working conditions, movement of information etc. was regularly surveyed and the results used for improvement purposes. The majority of assessment committees found that the use of the financial resources of the institutions, administration and the development of infrastructure were based on their development plans and on the needs of society. Generally, the institutions provide education to a high level, enabling graduates to compete in the local and international labour markets, and use modern technical and educational means in the teaching process. At the same time, the procurement of funds necessary for the research and development and creative activities (RDC) proved to be very difficult (especially in professional higher education institutions). In the field of management, the determining of key results earned the most 
criticism, which is partly related to shortcomings in establishing and measuring the results of $\mathrm{RDC}$. Internationalisation is a topic that was underscored by all of the assessment committees in one way or other. Activities related to internationalisation are currently sufficient only in a few larger institutions; the remainder having a lot of room for development in this regard.

Based on the results of both stages of the analysis, a number of strengths that generally characterise Estonian institutions of higher education should be highlighted:

1. Planning of the development of institutions of higher education is detailed and based on mission and vision alike, and takes into account the priorities established by the Estonian state;

2. Senior management copes well with the role of the leader and the involvement of members of management in the decision-making process is at a good level;

3. The professional development of employees is supported in various forms and it has intensified thanks to EU structural funds;

4. The infrastructure of institutions of higher education is excellent and its development has taken priority directions into consideration;

5. In opening study programmes, institutions of higher education are guided by their strategic goals whilst taking into consideration the needs of the labour market and the expectations of the society;

6. Various forms of information technology are used in the teaching process;

7. Graduates of Estonian higher education institutions are competitive in local and international markets.

At the same time, the Estonian higher education faces a number of challenges in forthcoming years:

1. Focusing on the strengths of the institutions of higher education, determining key areas;

2. Steadfastly implementing structural changes;

3. Minimising financial risks arising from the possible decrease in the number of students at the end of the EU structural fund period;

4. Reducing drop-outs by approaching each student individually and offering early support;

5. Applying more formative assessment in the teaching process by providing students with detailed feedback of their learning outcomes;

6. Ensuring quality supervision for students in writing their final theses at all levels of study;

7. Integrating the international aspects into all main processes of the institution of higher education.

Keywords: higher education institutions, institutional accreditation, strategic management, organisation development 